\title{
Media and Social Work
}

\author{
Afrin Jahan ${ }^{1}$, Md. Mahbubur Rahman ${ }^{2}$
}

\begin{abstract}
Media plays a substantial role providing the public with information about social workers, the people they serve and the public perception of issues affecting vulnerable group. This write-up provides a platform for public discussion and plays a key role in forming public opinion about what social workers do and how well they can do it. Negative and inaccurate reporting of visual and also the print media undermines public confidence and challenges the professionalism of social workers thereby increasing risk to the vulnerable group of the society as the social worker are dealing with them. Resolving this conflict is challenging; social workers and journalists have motivations, accountabilities and structural issues that may build inaccurate media portrayal of social work related stories. This article focuses on the potential of interprofessional education to better manage these barriers, producing socially responsive journalists and media friendly social workers.
\end{abstract}

Keywords: Media and Social Work, social workers, vulnerable group, journalists and media, vulnerable public, human Relationships, digital communication, television violence, visual media, advertisements

\section{Introduction}

It is an established fact that the media helps shape public concerns about social problems and specifically about the issues with which the social work professions contend (Franklin and Parton 1991). While social work is represented in the media as being about the protection of the vulnerable group, social work is also concerned with promoting the rights and interests of marginalized and vulnerable public (General Social Care Council 2011 GSCC hereafter).

In today's digitized world human Relationships increasingly negotiated through social media interaction and digital communication. Social media significantly require Emailing-Texting-Websites-Apps-Blogs-Twitter, etc which in turn create new social skills, new communication skills, new social awareness, new social possibilities and also new potential pitfalls. (Gloria Kirwan Trinity College Dublin).

\section{Literature Survey}

Aldridge (1990) urges that, "media organizations are driven by considerations of costs and profits" (p.612) and suggests that, "...social work"s bad news provides sex and violence in abundance" (p.617), the bread and butter, arguably, of the press media. It is also clear that the press inculcate immediacy and drama which, "slant the selection of stories towards the more sensational" (Ayre 2001 p.889).

Media interest in social work and specifically child abuse can be traced back to the death of Maria Colwell in 1973. Media constructions of social work are often linked to failings which have been highlighted in public inquiries or, as in the case of the Cleveland crisis, the press and broadcast media actually leading the public awareness campaigning element (Aldridge 1990; Kitzenger 2000). Franklin and Parton (1991) argue that, "child abuse inquiries have been the major triggers of media interest as well as their primary focus" (p.12). In the Cleveland public inquiry into the way in which children were removed from their parents, the press reporting of the issues was discussed in an entire section of the published report (Franklin and Parton 1991) which criticized the press for their role in continuing the crisis.
In the media reporting of the Beckford, Carlile and Henry cases the media:

“... constructed an extremely negative stereotype of social workers which presented them as incompetent, nonjudgmental and indecisive individuals ... extremely reluctant to intervene in the private realm of family life even to protect children from a suspected abusing adult" (Franklin and Parton 1991, p.14).

These media constructions gain valuable currency in the aftermath of child deaths and social work itself arguably comes to represent all that is wrong with public services, whilst social workers are represented as being all that is wrong with social work. Media reports often stereotype and provide simplistic but enduring constructions which do little to reflect the complexity and uncertainty which characterizes social work practice.

There is an abundance of research on the influence of television violence on children. The convergence of research demonstrates an association between heavy viewing of violence and aggressive behavior. Despite thirty years of research, regulatory policy has failed to decrease violence on children's television. Children exposed to high rates of violence on television may be at greater risk of developing school and social problems. This paper highlights both research and theory which explains the relationship of television violence to children. It further makes the case that television violence should be an important and legitimate concern for social work.

In the course of our life we meet every day the visual media: we watch television, read magazines, surf on the Internet, play computer games and see smaller or bigger posters everywhere in the city which advertising newer, better and more practical produces. However, these situations have already become so natural, that we usually don't realize how they impress us. Because of it, we tend to forget all about the next questions: What do we know about the effects of the visual media? How can it influence our way of thinking, deeds and of course our everyday life? Is it possible, that more or less the media direct every people e's life? If it is true, isnet it frightful? On the other hand, is it useful or harmful for us? Can the visual media give good example for young

\section{Volume 5 Issue 8, August 2016}




\section{International Journal of Science and Research (IJSR) \\ ISSN (Online): 2319-7064 \\ Index Copernicus Value (2013): 6.14 | Impact Factor (2015): 6.391}

people? All of these questions are very difficult and complex, but if we can squarely answer them, we can easily know the effects of the visual media.

At the beginning of this millennium the people couldn't see pictures at all and at the end of the same millennium, people next door to see only pictures, and discover the world just by lantern lecture." - wrote Péter Balassa aesthete in the last years of the twentieth century. Out of the almost countless visual information, we get day by day maybe the most impressive is the data from television. After this machine had spread widely around the world, the use of this mass communication medium became one of the animal needs. It was recognized by the TV channels, and laying hold of it, without too much limitation, they started to relay every kind of programmed in order to extend their watching and profit. However, some of them were very harmful for kids. Luckily, scientists started to deal with this problem anymore in the early 1970s, but the opinion of the society's majority about their research work was skeptical. Ten years later Rubinstein repeated the survey, but the conclusion was not better than last time: children, who watched more television than the others, became more aggressive in the course of playing. However, the American and other governments just in the early $1990^{\circ} \mathrm{s}$ started to deal with this problem. Maybe ever the most extensive study of this topic was made by the Columbia University. It finished in 2007 and the investigators monitored the changes of habits of more than 700 families over 17 years. The director of the project, Jeffry Johnson shortly concluded his experiences. „The immoderate television watching can contribute to develop syndromes which cause verbal and physical aggression, sleeping problems, obesity and attention and study difficulties. "Moreover, according to this survey the time, we spend watching television and our aggression level are directly proportional to one another. For example at the adults, who spent more than 3 hours watching television when they were 14 years old, the number of drastic actions were fivefold, than those people who were watching television at the most 1 hour in the same age. Maybe these results are dumbfounding, but we can't leave out of consideration the fact, that the environment in which we live, our mental outfit and of course, that when and what kind of program we are or were watching determine in large, how the television affect on us.

\section{Problem Definition}

In the course of our life we meet every day the visual media: we watch television, read magazines, surf on the Internet, play computer games and see smaller or bigger posters everywhere in the city which advertising newer, better and more practical produces. However, these situations have already become so natural, that we usually don't realize how they impress us. Because of it, we tend to forget all about the next questions: What do we know about the effects of the visual media? How can it influence our way of thinking, deeds and of course our everyday life? Is it possible, that more or less the media direct every people"s life? If it is true, isnet it frightful? On the other hand, is it useful or harmful for us? Can the visual media give good example for young people? All of these questions are very difficult and complex, but if we can squarely answer them, we can easily know the effects of the visual media.

The misinforming television programs often have a big share in influencing our way of thinking. What is more, television programs often dispossess kids of first hand experiences. It is a serious problem, because the observations are very important for the 8-12 year old age-group. It helps them form their own world view, develop relationships, friendships, and try to start their more or less independent life. This period determine how they can fit in the society and of course how they will react later the events of their life, which aren't always fair or happy. However, the television programs show children a complete, maybe isn't exactly true world, in which is easier and more comfortable than in the concrete. Moreover, in these imaginative worlds, usually the reactions of the people are really very different from the real. The ,bad boys ee are always rude, but instead of getting punishment, they usually get premium from their boss, who is also vulgar. At the same time, it isnet only the parameter of the „bad boys ${ }^{\text {ec }}$. Very often, good boys ${ }^{\text {ee }}$ practice aggression and break the rules in order to catch the offenders. What is more, according to a survey, the aggressive scenes are in the most stressful period of the films. All of these things can issue in, that those children, who watch a lot of television, can become adults, who think, that the world in which we live is as dangerous as those ones we see in the movies. Moreover, these people overrate the chance that they fall prey to crime, and they think that their neighborhood isn't safe enough. The last two things emphatically point at the biggest disadvantage of the television aggression: it has very serious character formative effect. However, the governments all over the world try to fight against with several methods the negative effects of the television.

Nowadays everybody has more or less information about the negative effects of the aggressive, rude and misinforming television programs, and luckily the governments try to do something against these immoral movies. It means that every television program are in four categories: without age limit, age limit 12, age limit 16 and age limit 18. Moreover, before a program, its category has to be shown in words and in writing, and until the number, a symbol have to be marked in one of the nooks of the screen. The American government had set earlier a symbol system, which was similar to the inland, but it wasn et so successful than it was expected. In Bangladesh there is no symbol system to broadcast the program as these categories.

\section{Methodology / Approach}

Using social media data for any purpose presents first of all a series of important technical challenges. At a general level, significant computer skills are required both in terms of gaining access to the data and using it for analysis, skills which are currently in quite short supply. For organizations this implies either hiring skilled staff or contracting out to a private consultancy which specialize in social data analytics, Off-the-shelf solutions do exist, but offer limited insight for those without sufficient awareness of how the internals of the system work. 


\section{International Journal of Science and Research (IJSR) \\ ISSN (Online): 2319-7064 \\ Index Copernicus Value (2013): 6.14 | Impact Factor (2015): 6.391}

Furthermore, organizations wishing to engage in their own analytics need a significant IT infrastructure to support them. Engaging in projects such as measuring the mood of the nation on Twitter involves a computer capacity which is capable of both collecting and storing significant quantities of data. The costs of storage are constantly decreasing, meaning that this infrastructure is not out of reach of small and medium sized organizations. But the costs involved are nevertheless worth considering.

A final and significant problem for social Work and media research concerns the extent to which sentiment measured on such networks can be attributed to "real people". As a result of the commercial value and significance of social media, a number of professional organizations exist which try to actively influence overall perceived sentiment. This occurs both through active engagement with the communities on these networks, and (more problematically for our purposes) through the creation of fake accounts which are designed to rebroadcast messages, to swell the friend / follower count of certain individuals, or otherwise make the overall social media landscape look different than it would do "naturally".

Finally, it is worth offering a brief discussion of many of the methodological challenges highlighted in section 1.2: the fact that social media users are not representative of the general public, that only a minority of users post the majority of content, that opinions which are posted are unsolicited, and that accurately assessing these opinions in an automatic way is difficult. We have discussed above a variety of methods for counteracting each individual problem; here it is worth mentioning the major general way of counteracting all of them, which are "benchmarking" social media measures. Benchmarking can be conducted in a variety of ways. We can compare two different concepts of interest at the same time, or we could track the same concept over a period of time, looking at whether a particular policy is getting more or less popular. At this relatively early stage in the development of social media research, these different types of benchmark measures are crucial for adding meaning to otherwise quite abstract figures, and instilling some trust in the overall method.

\section{Results \& Discussion}

From the television or the Internet we can easily get as much information as we want. This procedure is faster and more comfortable, than reading books. It is a very useful thing in our running world in which most of the people haven't got enough time to read carefully a profession book or go to a course. On the other hand, the effectiveness of learning from books depends on in large our own mental capacity. „More intelligent people can perfectly acquire the knowledge from only a written theme, but a spectacular presentation can stand the less intelligent people in good stead dee $^{\text {think Rene }}$ Webber, the researcher of the Santa Barbara University in California, who has already created some studies in Germany and in England in the topic of ,cognitive and emotional effects of television and new technology media, especially new generation video games"e. Moreover, the information, which we find on the internet can inconsistent and inexact, so if we need accurate data, we should expend time and tiredness on read a book, instead of using the Internet.

\section{Future Scope}

Taking all things into consideration, I think, that the effects of the visual media can be good, as well as bad. In my opinion, every part of the media, but especially the visual media affect on us in large. I think, that it can change our way of thinking, worldview and of course our everyday life. On the other hand, I believe, that its character formative effect depends on only us. Every adult has to decide on his or her own, to what he or she gives credit and what television programs, web sites and magazines he or she let his or her children watch. I hope that in this way the negative effects of the visual media will be reduced, and its positive effects will be gained more ground.

\section{Conclusion}

Last, but not least, let's see a media genre with which we meet may the most, but we often don't realize how much influence our everyday life. It usually doesn't have rude or aggressive part, but we can't enunciate that it hasn't got negative effect. The genre, I think is the advertisement. We meet them everywhere: in the cities, on the buses and trams, in the television, and of course on the Internet. They plead with everybody to buy the showed product, or try out a service. On the surface, there isnet any problem with the advertisements. They seem to be only harmless short movies or smaller or bigger pictures, but there is very serious business interest behind them. What is more, the sometimes funny and kind, at other times scientific and objective advertisements next door to always suggest that we can't live whole life without their product. These things are often popularized by famous actors, actresses, sportsmen or singers, because lots of people think, that, if a successful people use them, they can be only impressive. Moreover, the companies always pay attention to the public can see their advertisements very often. In this way, they put them into newspapers and magazines, near busy roads, between popular films in the television and on the main pages of successful web sites. Nevertheless, we have to see, that the advertisements (similar to the other media genre) have the biggest effect on young children. Companies often try to play upon their credulity and suggestibility in order to raise their own popularity and profit. Luckily (also similar to other genres), governments try to place within definite bounds the advertisements.

\section{References}

[1] Ágnes Antalné Dr. Szabó - Judit Dr. Raátz. Magyar nyelv és kommunikáció; Tankönyv a 7-8. évfolyam számára. Nemzeti Tankönyvkiadó. Budapest. 2003.

[2] Beáta Horváth. Mozgókép- és Médiaismeret. Nemzeti Tankönyvkiadó. Budapest. 2004.

[3] Dóra Szabó. Erőszak a képernyőn: következmények és veszélyek.

http://www.palya.hu/dolgozat/dolgozat.cfm?id=1720 updated: 2002. 03. 18.

\section{Volume 5 Issue 8, August 2016}




\section{International Journal of Science and Research (IJSR) \\ ISSN (Online): 2319-7064}

Index Copernicus Value (2013): 6.14 | Impact Factor (2015): 6.391

[4] Elemér Hankiss. Diagnózisok 2. Magvető Kiadó. Budapest. 1986.

[5] Emese Gulyás. Reklám és etika. http://www.tudatosvasarlo.hu/cikkek/180 updated: 2005.01.17.

[6] Entertainment Software Rating Board. Game Ratings \& Descriptor Guide. http://www.esrb.org/ratings/ratings_guide.jsp updated:

[7] Gábor Apats. Akik háttal ülnek a tévének. http://www.origo.hu/teve/20070719-steven-spielberggillian-anderson-es-masok-elutasitjak-a-tevet.html updated: 2007. 07. 23.

[8] György Jánosi. A szórakozás történelmi funkcióváltozásai. Magvető Kiadó. Budapest. 1986.

[9] Ildikó Mihályi. A tévékor gyermekei.

[10] http://www.oki.hu/oldal.php?tipus=cikk\&kod=1999-11kf-Mihaly-Teve updated: 1999. 11.

[11] Judit Kiss. A televízió hatása a kisiskolás gyerekekre. http://www.oki.hu/oldal.php?tipus=cikk\&kod=2004-09ta-Kiss-Televizio updated: 2004. 09.

[12] ORIGO. Nem vált be a V-chip: a távirányító még a szülők kezében van. http://www.origo.hu/teve/20010727nemvalt.html updated: 2001. 07.27.

[13] ORTT. Korhatár-besorolások és jelölések.

[14] http://www.ortt.hu/belso_oldal.php?belso_id=12 updated:

[15] Richárd Balázs. A média és a játékok hatása agyunkra. http://www.sg.hu/cikkek/52048/ updated: 2007. 05. 11.

[16]Szilvia Szilárdy. Audiovizuális gyermek- és ifjúságvédelem az EU tagországaiban: ahány ház, annyi szokás.

[17] http://www.ortt.hu/uploads/9/12/1145885517gyermekve d.pdf updated: 2001. 12. 03.

[18]Zsuzsa Gátainé Sróth - Mária Csengeri - Lajos Varga. Mozgókép és médiaiismeret. Pauz-Westermann Kiadó. Celldömölk. 2004

[19]Ayre, P. (2001) Child Protection and The Media: Lessons from the last three decades. British Journal of Social Work 31, p.887-891.

[20] Aldridge, M., (1990) Social Work and the News Media: A Hopeless Case? British Journal of Social Work 20, p.611-625.

[21] Brocklehurst, D.,(2011)

Exile. http://www.bbc.co.uk/programmes/b0110cpy (Accessed 27th May 2011).

[22] Community Care (2009) Community Care to monitor media picture of social work profession. Community Care, 4/2/2009, Issue 1764.

[23] Community Care (2009) Stand Up Now for social work - what you can do. URL http://www.communitycare.co.uk/Articles/2009/07/06/1 10972/Stand-Up-Now-for-social-work-what-you-cando.htm (Accessed 12th September 2011).

[24] Franklin, B, and Parton, N. (1991) Social Work, The Media and Public Relations. Routledge.

[25] Henderson, L., and Franklin, B., (2007) Sad not Bad: Images of Social Care Professionals in Popular UK television Drama. Journal of Social Work. No. 7, pp. 133-153.

[26] Kitzenger, J., (2000) Media templates: patterns of association and the (re)construction of meaning over time. Media Culture and Society. (No.22, pp.61-84).
[27] Loach, K. (1994) Ladybird, ladybird

[28] http://www.imdb.com/title/tt0110296/ (Accessed 27th May 2011).

[29]Loach,K.,(1966) Cathy come home.

[30] http://www.screenonline.org.uk/tv/id/438481/index.htm 1 (Accessed 27th May 2011).

[31] Stone, S., Ekman, E., English, D., and Fujimori, S., (2008) Teaching notes: Collaboration among social work and journalism students and faculty: An instructional model. Journal of Social Work Education, Vol. 44, No. 1.

[32] The College of Social Work. URL http://www.collegeofsocialwork.org/index.asp (Accessed 24th April 2011).

[33] The General Social Care Council (2011) What is Conduct?

URL http://www.gscc.org.uk/page/5/Conduct.html (Accessed 24th April 2011).

[34] The Health Professionals Council. URL http://www.hpc-uk.org/ (Accessed 24th April 2011.

[35] Townsend, P., and Abel-Smith (1966) The poor and the poorest. G. Bell \& Sons.

\section{Author Profile}

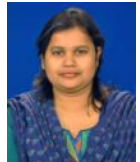

Afrin Jahan have completed the Master degree (MSS) from University of Dhaka Bangladesh in Social Welfare with first class. In spite of being a student of Social Science I think Social Welfare/Work is always found as one of my favorite subjects. Now people are trying hard merging all subjects of all fields together for the better understanding and better career. To ensure the sustainable use of the natural resources we need to build a relation between the Resources and the Economic Development here. I am an independent person that is determined to succeed. To me, challenges are chances of innovations and failures are motives for effort. I aim for perfection and development myself. I am a Professional person. I am working at Bangladesh Television (Only state run Television in Bangladesh) as a senior News reporter. I am working here with my sincerity and dedication. As a Journalist I always interested about International media. That is why I am writing here about this interesting topic.

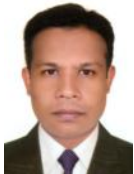

Md. Mahbubur Rahman is a media specialist with more than $\mathbf{1 5}$ years of experience in the field of Media, Health and Communications. Areas of his past roles include news writing, news editing, giving lectures, Research activities and writing up research. Md. Mahbubur Rahman started his media career as a Programme Organizer in 2001 in Bangladesh Betar (Radio Bangladesh) and now he is working as a Senior News Producer in Bangladesh Television. He is a member of Bangladesh Civil Service (BCS), Information Cadre of Bangladesh Government. $\mathrm{He}$ is also a Registered Pharmacist of Bangladesh.

\section{Volume 5 Issue 8, August 2016 www.ijsr.net}

